\title{
UTILIZATION OF INFORMATION TECHNOLOGY FOR REALIZATION OF GOOD GOVERNANCE IMPLEMENTATION IN THE PILOT PROJECT AREA AT RAJABASA IN BANDAR LAMPUNG
}

\author{
Sri Purwiyanti ${ }^{*}$, Yetti Yuniati ${ }^{1}$, Diah Permata $^{1}$ \\ ${ }^{I}$ Faculty of Engineering, Lampung University, Bandar Lampung, Indonesia \\ *Correspondence Author: sripurwiyantisurya@yahoo.com
}

\begin{abstract}
Implementation of good governance's principles at Rajabasa, Bandar Lampung has not done well. It caused by the lack of communication between government (public officials) and citizens. Therefore, the purpose of this public service activity is to resolve the problem by using information technology. The activity chooses a smaller government scope, which is a neighborhood area. The activity involves two steps, which is website creation and training step. The website contains are statistic data of citizens, procedures to apply the resident documents completing with the required forms, activities announcement, interactive forum for conveying critics and suggestions between citizens and government, and promotion forum for industry players. As a result, the website successfully displays a variety of information needed by citizens, and provides a means of communication for citizens and public officials. Training step about procedure for using the website also has been done. Certainly, evaluation about the liveliness of citizens in accessing the website is still required. However, good communication, efficiency, and effectiveness can begin to form well, which leads to better implementation of good governance.
\end{abstract}

Keywords: good governance, information technology, public service

\section{INTRODUCTION}

A good relationship between the government and the citizens plays a key role in order to realize our common goal which is towards a fair and prosperous Indonesia. Implementation of a good governance principle is capable to realize the relationship (Dikti, 2013;2014). However, the implementation should be done as much as possible by improving facilities and infrastructure to improve the quality of public services (Fera et al.,).

At Rajabasa, Bandar Lampung, implementation of good governance's principles has not done well. It is indicated by: (1) lack of information obtained by the citizens regarding the procedures for applying resident documents, (2) lack of citizen participation to convey their aspirations, and (3) lack of communication between the governments (village officials) and the citizen. For that purpose, this public service activity is aimed to overcome these problems by utilizing the progress of Information Technology.The activity chooses a smallest government scope, which is a neighborhood area. Methods used include two things, which are website creation and socialization / counseling. The website contains statistic data of citizens, procedures to apply the resident documents completing with the required forms, activities announcement, interactive forum for critics and suggestions between citizens and government, and promotion forum for industry players.

\section{PROBLEM FORMULATION}

Based on survey results at neighborhood Nunyai, Rajabasa, Bandar Lampung, it is known that implementation of good governance' principles has been not done optimally. From the conditions found in the situation analysis above it can be formulated some problems as follows:

1. Lack of information obtained by the citizens regarding the procedures for applying resident documents

2. Lack of information obtained by the citizens about the condition of their village

3. Lack of public participation to convey their aspirations

4. Lack of communication between the governments (village officials) with the citizens.

\section{BASIC THEORY}

Good Governance can be defined as an activity, process, or quality to govern. To establish good relationships between government and citizens, a concept called good governance was built. Different with previous government concept, this concept provides a large portion to the citizens to play an active role in the management of the state (Sedarmayanti, 2010) and also to industry players. Therefore, policies produced by the government are the result of 
consultation and dialogue between the parties affected by the policy. The implementation of good governance covers various aspects, such as participation, transparency, efficiency, and so on. This concept is excellent when applied thoroughly starting from the smallest level of government, such as neighborhood scope.

From the definition of good governance, it is formed some new paradigm of development, as follows:

1. It is not area to be developed, but area develop

2. It is not public to be developed, but public develop

3. Government duty is as a fasilitator or servant in the development.

The principles of good governance are participation, rule of law, transparency, equality, responsiveness, vision, accountability, control, efficiency \& effectiveness, and professionalism (Hardjasoemantri, 2003). For the establishment of good governance, the role of three actors, i.e. government, industry sector, and society, is needed. The government's duty is in charge of creating a good environment for political and law activity. The Private Sector is in charge of providing employment and income. Civil society facilitates socio-political interaction and motivates people to participate in social, political and economic activities. Pattern of relations among the actors is shown in Fig. 1.

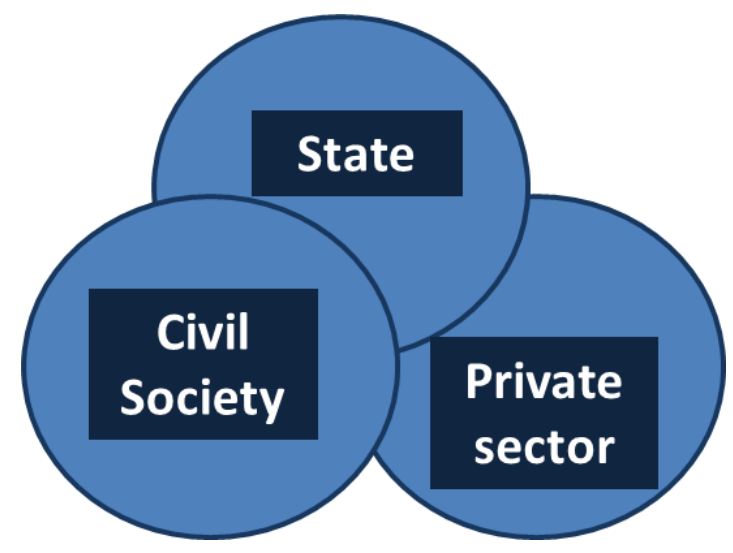

Fig. 1. Relation pattern among the actor of good governance.

\section{PURPOSE}

Purpose of this public service activity includes two parts, as follows:

\section{A. General Purpose}

The general purpose is to help the realization of good governance in Indonesia through its smallest scope, which is on the neighborhood scale, by utilizing internet-based information technology.

\section{B. Specific Purpose}

The specific purposes are:

1. Creating a website that can be accessed by all citizens of neighborhoods. The website contains are statistic data of citizens, procedures to apply the resident documents completing with the required forms, activities announcement, interactive forum for critics and suggestions between citizens and government, and discussion forum among the citizens.

2. To obtain a real and accurate statistical data of citizens in an updated and continuous manner.

3. For improving the efficiency and effectiveness of applying process to obtain administrative documents of residence.

4. To maintain effective communications between village officials and citizens so as to increase the participation of citizens in the activities of neighborhood.

5. To maintain effective communication among the citizens.

\section{METHOD}

This public service activity has been done in the several steps as shown in Fig.2. Step 1 is identification. Identification is needed for knowing neighborhood's condition. In this step, a survey has been carried out by giving a questionnaire to the citizen. Questions in the questionnaire consist of two parts. The first part is the questions about the availability of information and the second part is about the availability of means to convey aspirations.

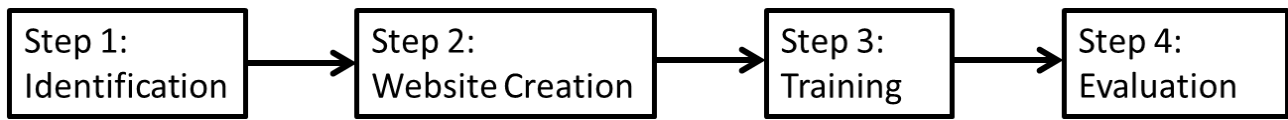

Fig.2. Activity Method 
The second step is the continuation of the identification activity, which is to provide the technology package. At this step, we design and create website that can meet the public needs. At this step also, data entry has been done which includes: neighborhood' profile, statistic data, and procedures for applying resident documents, and so on.

The third step is socialization and training. Socialization has been done by sharing information with the neighborhood's citizens. The citizens are led to know the website that has been created so that the community can feel its usefulness. Training is done to provide knowledge about how to access and how to use the website, so that people can use it effectively and efficiently.

The fourth step is evaluation step to determine the success of this activity. The evaluation is done at the end of the activity by comparing the conditions before and after the training phase. Evaluation is used to assess whether the technology package provided is appropriate for the purpose or not.

\section{RESULTS}

This activity includes four steps, as described previously. Therefore the results can be described based on the results of the activities of each step. The results of the survey step are shown in Table 1 for 40 respondents. From the survey's results we know that application of good governance principles is in the low level, especially for the principle of transparency (availability of information) and aspirations, so it needs to be made a media that can overcome the problem.

Table 1.

\begin{tabular}{|c|l|c|c|c|}
\hline \multirow{2}{*}{ No } & \multicolumn{1}{|c|}{ Type of Survey } & \multicolumn{2}{c|}{ Answered (\%) } \\
\cline { 3 - 5 } & & Available & Hesitate & $\begin{array}{c}\text { Not } \\
\text { Available }\end{array}$ \\
\hline 1 & Part 1: questions about the availability of information & 10 & 20 & 70 \\
\hline 2 & $\begin{array}{l}\text { Part 2: questions about the availability of means to } \\
\text { convey aspirations }\end{array}$ & 20 & 20 & 60 \\
\hline
\end{tabular}

At the second step, the website has been created with address www.rt05rajabasanunyai.id. The website display is shown in Fig. 2 for home menu. The website includes several menus as follows:

a) Profile and History

This section should contain information about the history of neighborhood, but due to unavailability of information then this section is not yet filled at this time.

b) Announcement

This section provides information about the neighborhood's activities that have been done. This section also provides space for citizens to convey some comments or responses about the activities undertaken. Uploaded comments will be displayed in the comments field.

c) Location map

This section connects automatically with Google maps that provide information about the location of the neighborhood at Nunyai, Rajabasa.

d) Village Institution

This section is provided for the development stage if one day this website will be used for a wider scope, for example urban area that consisting of several neighborhoods.

e) Village statistic

This section contains information about the statistical data of Nunyai's citizens. The data available here include job data, education, religion, marital status, and so on as shown in Fig. 3. 


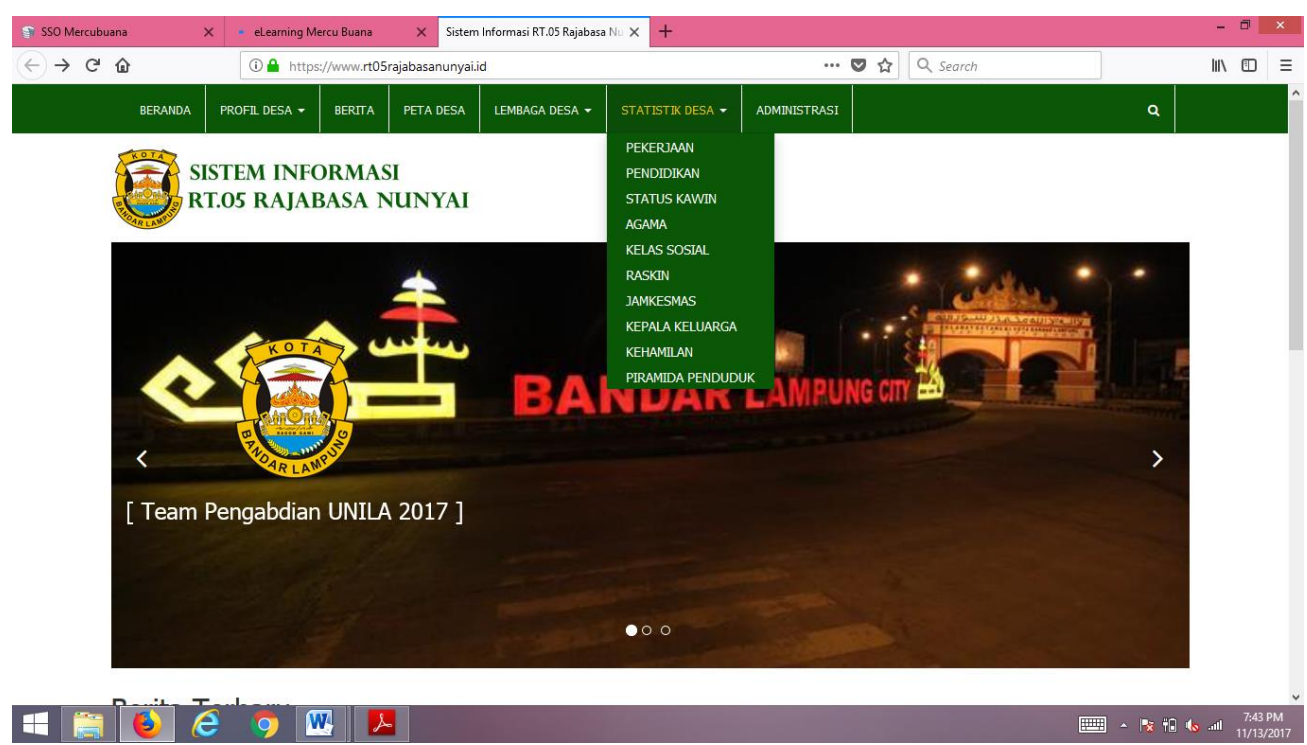

Fig.3. Menu of Village Statistic

The data presented in the form of graphs and tables. For example, Fig. 4 shows the graph of citizen's education data.

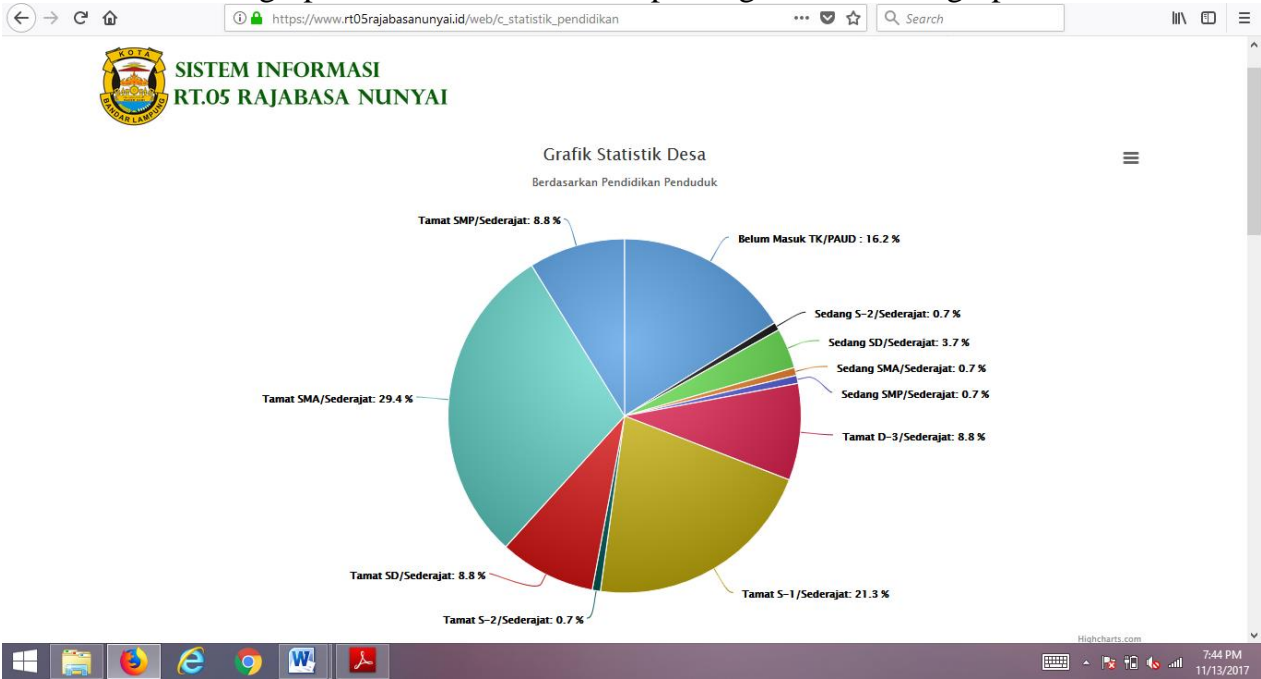

Fig.4. Statistical graph of the education level of the citizen in Nunyai neighborhood

f) Administration

This section provides information about some regulation for applying various residence documents completed with procedures and forms that can be downloaded. The documents include identity cards (KTP), birth certificates, and Family Card (KK). The display on the website is shown in Fig. 5. 


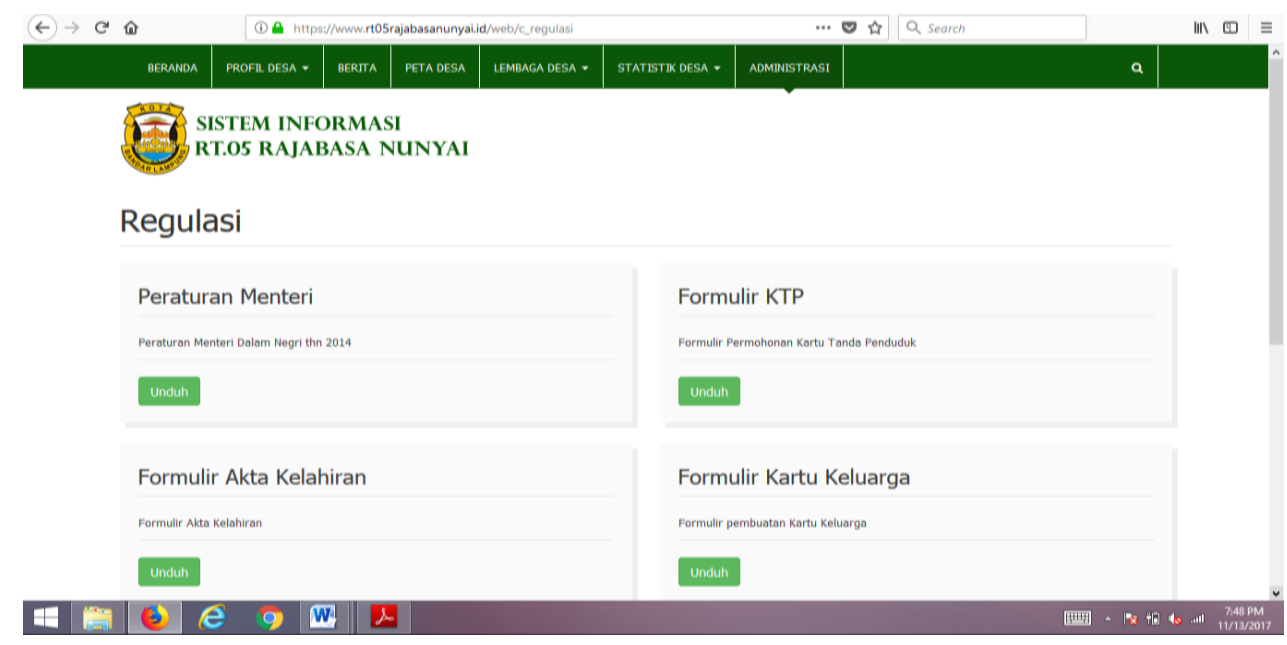

Fig. 5. Views of the website about the regulation of some resident documents

g) Criticism and suggestions

By this menu, residents can submit critics and suggestions to public official by sending them directly through this website. For that, citizens are required to login first using the user name and password provided.

At the socialization step, we share some information about how to access and how to use the website and a about the principles of good governance. This activity has been held on Saturday, November $3^{\text {rd }}, 2017$ in Nunyai neighborhood Rajabasa. This activity was attended by 40 residents of various jobs, gender, and age. At the end of this activity, posttest is given with the same question with the survey. The results are the level of public answer about the ease of getting information increased to $100 \%$ and about the means of channeling aspirations also become $100 \%$.

Evaluation step is done to see the activity of residents in using website which have been made. Currently this stage has not been implemented because ideally this step is done during the 3 months, 6 months, and 1 year after the socialization activities conducted. Therefore further evaluation is needed which is useful for the development of this activity on a wider scope.

\section{CONCLUSION}

We have finished public service activity about how to improve the implementation of the principles of good government by using website creation and socialization method. As a result, by using the website, now citizen at Nunyai Rajabasa obtain information about procedure to applying resident documents, activities, village's profile, and so on. They also obtain a media for conveying their critics and suggestion. Therefore, the results lead to provide a better implementation of good governance principles, i.e, transparency, participation, effectiveness and efficiency. ACKNOWLEDGMENT

We thanks to Mr. Antoni, Head of Nunyai neighborhood at Rajabasa, Bandar Lampung.

\section{REFERENCES}

Pendidikan Kewarganegaraan Untuk Perguruan Tinggi, Dikti, Jakarta, 2014.

Modul Kuliah Kewarganegaraan Dikti, Jakarta, 2013

Fera, F., Kadir, A., and Sahrun, “ Penerapan Prinsip-Prinsip Good Governance dalam Proses Pelayanan Publik pada Kecamatan Perigi Kabupaten Muna", University of Halu Oleo, http://sitedi.uho.ac.id/uploads_sitedi/C1A114396_sitedi_jurnal\%20FETI\%20FERA.pdf

Sedarmayanti, Reformasi Administrasi Publik, Reformasi Birokrasi, dan Kepemimpinan MasaDepan Mewujudkan Pelayanan Prima dan Kepemimpinan yang baik, Bandung: PT.RefikaAditama, 2010.

Hardjasoemantri, Kusnadi "Good Governance dalam Pembangunan Berkelanjutan di Indonesia", presented at Lokakarya Pembangunan Hukum Nasional VIII, Bali 2003. 